Cytogenet Genome Res 105:159A (2004)

DOI: 10.1159/000078023

\title{
Assignment of the murine
} ankyrin-repeated protein gene (Ankrd2) to mouse chromosome $19 C 3 \rightarrow D 1$ and rat chromosome $1 \mathrm{q} 51 \rightarrow$ q53 by fluorescence in situ hybridization

M. Fujiwara, a, b Y. Tsukamoto, ${ }^{c}$ A. Miyazaki, ${ }^{c}$ M. Moriyama, ${ }^{c}$ and H. Satoha

a Division of Pathology, Department of Cancer Biology, The Institute of Medical Science, The University of Tokyo;

b Pathology Division, KOTOBIKEN Medical Laboratories Inc.;

c Department of Molecular Biology, Faculty of Medicine, Tottori

University (Japan) 